\section{Earth sciences and biodiversity fall victim to budget plan}

Rex Dalton, San Diego

Two major collaborative projects costing some $\$ 175$ million are among the casualties of the budget proposal for 2002 put forward this month by the National Science Foundation (NSF).

EarthScope, a comprehensive study of North America's lithosphere and crust, and the National Ecological Observatory Network (NEON), a proposal for long-term biodiversity monitoring, are among major facilities which the NSF left out of its request.

Agency officials say the lack of any extra research funding in the $\$ 4.5$ billion NSF budget left no room to make a start on either project next year. Researchers involved in years of planning for the projects, which had been approved by the National Science Board, the NSF's governing body, expressed bitter disappointment at the news.

"The community can get exhausted if it has to keep up this level of activity without any scientific return," says Mark Simons, a geophysicist at the California Institute of Technology who was involved in planning a component of EarthScope.

"It probably should come as no surprise," says James Beach, an informaticist at the University of Kansas involved in the planning of NEON. "Why build a national infrastructure to monitor long-term environmental trends, when the Bush administration [wants] to accelerate the private plunder of the country's natural capital?"

Some US researchers are now looking to an international effort to advance a component of EarthScope that would involve drilling 4 kilometres into the San Andreas fault near San Francisco to conduct seismology tests. Mark Zoback, a seismologist at Stanford University who helped plan this project, says that the International Continental Scientific Drilling Program at GeoForschungsZentrum in Potsdam, Germany, is considering support for a pilot drill hole $2 \mathrm{~km}$ deep. A decision is expected soon.

But such activity is a far cry from that envisaged under the original $\$ 75$ million Earthscope proposal (see Nature 405, $390-392 ; 2000$ ), which also included a satellite-based radar system and an array of 2,400 mobile seismometers deployed across the United States.

For NEON (see Nature 404, 216; 2000), scientists had sought $\$ 100$ million to build and equip 10 environmental monitoring sites.

\title{
Britain looks to wave-power site after researchers flee
}

David Adam, London

Britain is considering allocating a stretch of coast to research into wave and tidal energy, after planning regulations forced an emerging tidal-power company to flee to Iceland.

The new site would allow tidal and wave power to be assessed side by side and feed electricity into the national supply. The Scottish parliament has already suggested locating the site off the west coast of Scotland.

Britain's location and rugged coastline make it ideal for such research, but researchers say they have to obtain written planning consent from up to 14 different organizations.

“The only problem we've got [in Britain] is the lack of long-term planning," says John Hassard, co-founder of tidal-energy company RV Power. "We could have got permission for our installation in the Solent [off the south coast of England] but it would have taken between 18 months and two years."

The paperwork included forms from the coastguard, port authority, countryside groups, two local councils and three government departments.

The company will now install prototype equipment off the coast of Iceland. "We made one phone call," Hassard says. "A lady came down in a Land Rover, met us by the water and said 'Go ahead and build it. How

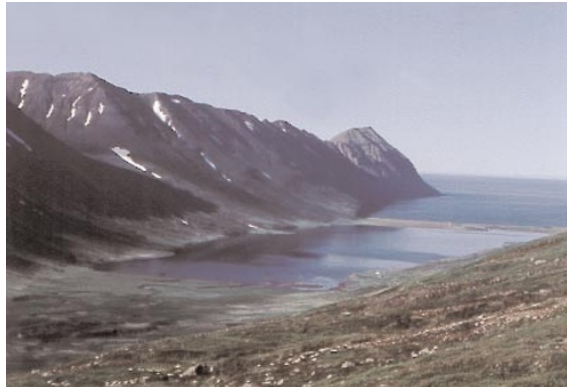

Iceland's coast proves hospitable to researchers.

can we help?"' Iceland is enthusiastic about renewable energy - geothermal sources satisfy much of its electricity demand.

Only a few such projects are scattered around Britain's coastline. "The problem we had was knowing where to start and who to talk to," says Charles Taylor, senior engineer with wave-power company Ocean Power Delivery in Edinburgh. He says Britain needs to improve its planning procedures.

UK energy minister Peter Hain told a recent parliamentary committee hearing: "There is a serious problem here, both in the sheer bureaucracy and in the associated costs." The committee's report on wave and tidal power is expected to appear in a few weeks, and to recommend the creation of a dedicated research site.

\section{Search is on for underwater volcano}

Rex Dalton, San Diego

A team of oceanographers is on a mission to track down and monitor an underwater volcano that has erupted about 300 kilometres off the coast of northern California.

The research vessel New Horizon sailed this month from its base at the Scripps Institution of Oceanography in La Jolla, California, to arrive at the suspected site of the volcano last week. So far, two days of attempts to find the Gorda Ridge's linear volcano - the eruptions of which were first detected by military sonar - have proved unsuccessful.

"It's like fishing, but a lot more expensive," says Ed Baker of the Pacific Marine Environmental Laboratory in Seattle, Washington, who is jointly leading the expedition.

The team plans to spend a week casting instruments 3,200 metres beneath the ocean surface to measure temperature and chemical composition, with the aim of locating the volcano's plume. The faster the vessel reaches the area, the better chance it has of finding the plume before it dissipates.
Oceanographers are seeking better equipment for examining volcanic events, as part of an international effort known as Dynamics of Earth and Ocean Systems (DEOS). This would include seismometers on the sea floor off the US Pacific coast.

DEOS has attracted some UK funding. But hopes of support from the US National Science Foundation have been hit by research funding restraints (see story, left).

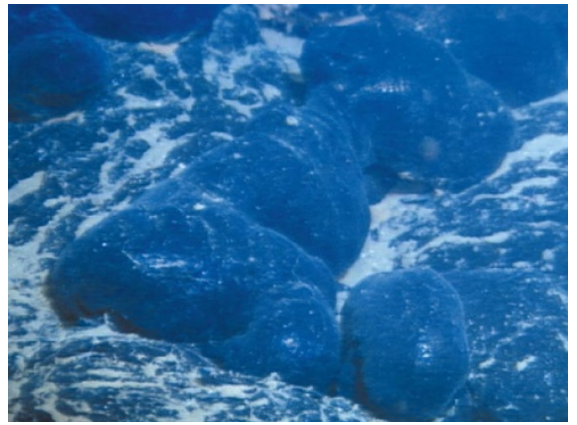

New lava on old: one sign of volcanic activity. 